\title{
A mixed-valent cyclodiphosphazane: Transition metal chemistry and cis/trans isomerisation
}

\author{
GUDDEKOPPA S ANANTHNAG ${ }^{\mathrm{a}}$, JOEL T MAGUE ${ }^{\mathrm{b}}$ and MARAVANJI S BALAKRISHNA ${ }^{\mathrm{a}, *}$ \\ ${ }^{a}$ Phosphorus Laboratory, Department of Chemistry, Indian Institute of Technology Bombay, \\ Powai, Mumbai 400 076, India \\ ${ }^{\mathrm{b}}$ Department of Chemistry, Tulane University, New Orleans, Louisiana 70118, USA \\ e-mail: krishna@chem.iitb.ac.in; msb_krishna@iitb.ac.in
}

MS received 12 December 2014; revised 22 January 2015; accepted 24 January 2015

\begin{abstract}
The hydrolysis of $c i s-\left\{\mathrm{ClP}\left(\mu-\mathrm{N}^{t} \mathrm{Bu}\right)_{2} \mathrm{P}\left(\mathrm{NH}^{t} \mathrm{Bu}\right)\right\}$ (1) produced a mixed $\mathrm{P}^{\mathrm{III}} / \mathrm{P}^{\mathrm{V}}$ derivative of cyclodiphosphazane, $\operatorname{cis}-\left\{\left({ }^{t} \mathrm{BuNH}\right) \mathrm{P}\left(\mu-\mathrm{N}^{t} \mathrm{Bu}\right)_{2} \mathrm{P}(\mathrm{O}) \mathrm{H}\right\}(\mathbf{2})$. The treatment of $\mathbf{2}$ with elemental selenium resulted in the formation of the monoselenide, trans $-\left\{\left({ }^{t} \mathrm{BuNH}\right) \mathrm{P}(\mathrm{Se})\left(\mu-\mathrm{N}^{t} \mathrm{Bu}\right)_{2} \mathrm{P}(\mathrm{O}) \mathrm{H}\right\}(3)$ in good yield. The reactions of two equivalent of 2 with $\left[\mathrm{Pd}(\mu-\mathrm{Cl})\left(\eta^{3}-\mathrm{C}_{3} \mathrm{H}_{5}\right)\right]_{2}$ or $\left[\mathrm{Ru}\left(\eta^{6}-p \text {-cymene }\right)(\mu-\mathrm{Cl}) \mathrm{Cl}\right]_{2}$ in dichloromethane afforded corresponding mononuclear complexes, $\left[\left(\eta^{3}-\mathrm{C}_{3} \mathrm{H}_{5}\right) \mathrm{PdCl}\left\{\left({ }^{t} \mathrm{BuNH}\right) \mathrm{P}\left(\mu-\mathrm{N}^{t} \mathrm{Bu}\right)_{2} \mathrm{P}(\mathrm{O}) \mathrm{H}\right\}\right](4)$ and $\left[\left(\left(\eta^{6}-\right.\right.\right.$ $p$-cymene $\left.\left.) \mathrm{RuCl}_{2}\right)\left\{\left({ }^{t} \mathrm{BuNH}\right) \mathrm{P}\left(\mu-\mathrm{N}^{t} \mathrm{Bu}\right)_{2} \mathrm{P}(\mathrm{O}) \mathrm{H}\right\}\right](5)$. The treatment of 2 with $\mathrm{M}(\mathrm{COD}) \mathrm{Cl}_{2}(\mathrm{M}=\mathrm{Pd}$ and $\mathrm{Pt})$ in dichloromethane at room temperature gave $\left[\mathrm{MCl}_{2}\left\{\left({ }^{t} \mathrm{BuNH}\right) \mathrm{P}\left(\mu-\mathrm{N}^{t} \mathrm{Bu}\right)_{2} \mathrm{P}(\mathrm{O}) \mathrm{H}\right\}_{2}\right](6 \mathrm{M}=\mathrm{Pd} ; 7 \mathrm{M}=\mathrm{Pt})$ in good yield. Owing to the cis/trans isomerisation of the cyclodiphosphazane rings, the complexes 6 and 7 exist as a mixture of two isomers. Various NMR spectroscopic techniques were employed for structural elucidation. The molecular structures of $\mathbf{5}$ and $\mathbf{7}$ were established by single crystal X-ray crystallographic studies.
\end{abstract}

Keywords. Cyclodiphosphazanes; cis/trans isomerisation; NMR studies; complexes

\section{Introduction}

Cyclodiphosphazanes or diazadiphosphetidines are a major class of cyclic phosphorus-nitrogen compounds..$^{1,2}$ They find applications in various fields such as coordination chemistry, ${ }^{3-8}$ in anti-tumour studies ${ }^{9,10}$ and in catalytic organic transformations. ${ }^{11-13}$ The dichlorocyclodiphosphazanes, $c i s-\{\mathrm{ClP}(\mu-\mathrm{NR})\}_{2}$, have been effectively explored as building blocks in the synthesis of a large range of phosphorus-nitrogen macrocycles. ${ }^{14-20}$ Cyclodiphosphazanes can exist as cis and trans isomers in solution as well as in the solid state (chart 1, A and B). ${ }^{2}$ The ring conformations of these isomers can be established by single crystal X-ray diffraction studies or by ${ }^{31} \mathrm{P}$ NMR data, where the $c$ is isomers show upfield chemical shifts compared to the trans analogues. ${ }^{21}$ The cis/trans interconversion in solution is observed for several cyclodiphosphazanes. The interconversion can proceed through edge $(\mathrm{N})$ or vertex $(\mathrm{P})$ inversion. ${ }^{22}$

The cis cyclodiphosphazanes act as versatile bridging ligands for the construction of polynuclear metalomacrocycles, or one- (1D), two- (2D), and three-dimensional (3D) coordination polymers and their transition metal chemistry has been extensively studied. ${ }^{23-25}$ The

*For correspondence coordination chemistry of the trans isomer has been much less studied. ${ }^{26-29}$ Recently we explored the coordination chemistry of acyclic dimers of cyclodiphosphazanes derived from cis- $\left\{\mathrm{ClP}\left(\mu-\mathrm{N}^{t} \mathrm{Bu}\right)_{2} \mathrm{P}\left(\mathrm{NH}^{t} \mathrm{Bu}\right)\right\} .{ }^{14,30,31}$ Hydrolysis of the $\mathrm{P}-\mathrm{Cl}$ bond in $c i s-\left\{\mathrm{ClP}\left(\mu-\mathrm{N}^{t} \mathrm{Bu}\right)_{2} \mathrm{P}\left(\mathrm{NH}^{t} \mathrm{Bu}\right)\right\}$ to produce cis- $\left\{\left({ }^{t} \mathrm{BuNH}\right) \mathrm{P}\left(\mu-\mathrm{N}^{t} \mathrm{Bu}\right)_{2} \mathrm{P}(\mathrm{O}) \mathrm{H}\right\}$ was reported by Wright and co-workers, ${ }^{32}$ while a similar compound was accidentally isolated by Kumaraswamy and co-workers. ${ }^{33}$ Herein we report transition metal chemistry and cis/trans isomerisation of $c i s-\left\{\left({ }^{t} \mathrm{BuNH}\right) \mathrm{P}(\mu\right.$ $\left.\left.\mathrm{N}^{t} \mathrm{Bu}\right)_{2} \mathrm{P}(\mathrm{O}) \mathrm{H}\right\}$.

\section{Experimental}

\subsection{General procedures}

All manipulations were performed using standard vacuum-line and Schlenk techniques under nitrogen atmosphere unless otherwise stated. All the solvents were purified by conventional methods ${ }^{34}$ and distilled prior to use. The compounds, cis- $\left\{\mathrm{ClP}\left(\mu-\mathrm{N}^{t} \mathrm{Bu}\right)_{2} \mathrm{P}(\mathrm{NH}\right.$ $\left.\left.{ }^{t} \mathrm{Bu}\right)\right\},{ }^{35}\left[\mathrm{Pd}(\mu-\mathrm{Cl})\left(\eta^{3}-\mathrm{C}_{3} \mathrm{H}_{5}\right)\right] 2,{ }^{36}\left[\mathrm{Ru}\left(\eta^{6}-p\right.\right.$-cymene $)(\mu$ $\mathrm{Cl}) \mathrm{Cl}]_{2},{ }^{37} \mathrm{Pd}(\mathrm{COD}) \mathrm{Cl}_{2},{ }^{38}$ and $\mathrm{Pt}(\mathrm{COD}) \mathrm{Cl}_{2},{ }^{38}$ were prepared according to the published procedures. Other chemicals were obtained from commercial sources and purified before use. 


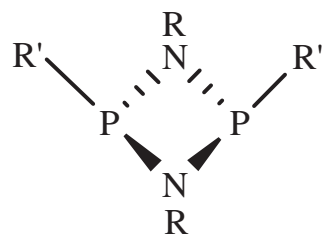

A

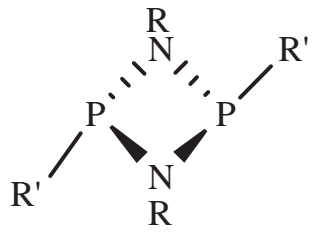

B
Chart 1. Cis and trans-cyclodiphosphazanes.

\subsection{Instrumentation}

The NMR spectra were recorded at the following frequencies: $400 \mathrm{MHz}\left({ }^{1} \mathrm{H}\right), 162 \mathrm{MHz}\left({ }^{31} \mathrm{P}\right), 100 \mathrm{MHz}$ $\left({ }^{13} \mathrm{C}\right)$ and $107.5 \mathrm{MHz}\left({ }^{195} \mathrm{Pt}\right)$ using Varian VXR 400, Bruker AV 400 or AV 500 spectrometers. The ${ }^{13} \mathrm{C}$, ${ }^{31} \mathrm{P}$ and ${ }^{195} \mathrm{Pt}$ NMR spectra were acquired using broadband proton decoupling. The spectra were recorded in $\mathrm{CDCl}_{3}$ solutions with $\mathrm{CDCl}_{3}$ as an internal lock; chemical shifts of ${ }^{1} \mathrm{H}$ and ${ }^{13} \mathrm{C}$ NMR spectra are reported in ppm downfield from TMS, used as internal standard. The chemical shifts of ${ }^{31} \mathrm{P}$ and ${ }^{195} \mathrm{Pt}$ NMR spectra are referred to $85 \% \mathrm{H}_{3} \mathrm{PO}_{4}$ (in $\mathrm{D}_{2} \mathrm{O}$ ) and $\mathrm{K}_{2} \mathrm{PtCl}_{6}\left(\right.$ in $\mathrm{D}_{2} \mathrm{O}$ ), respectively, used as an external standard. Microanalyses were performed using a Carlo Erba Model 1112 elemental analyzer. Mass spectra were recorded using Waters Q-Tof micro (YA-105). The melting points were observed in capillary tubes and are uncorrected.

\subsection{Synthesis of cis- $\left\{\left({ }^{t} \mathrm{BuNH}\right) P\left(\mu-N^{t} \mathrm{Bu}\right)_{2} \mathrm{P}(\mathrm{O}) \mathrm{H}\right\}(2)^{32}$}

A solution of $c i s-\left\{\mathrm{ClP}\left(\mu-\mathrm{N}^{t} \mathrm{Bu}\right)_{2} \mathrm{P}\left(\mathrm{NH}^{t} \mathrm{Bu}\right)\right\}$ (1) (1.1 g, $3.528 \mathrm{mmol})$ in THF $(20 \mathrm{~mL})$ was added dropwise to a solution of water $(0.064 \mathrm{~g}, 3.528 \mathrm{mmol})$ and triethylamine $(0.54 \mathrm{~mL}, 0.39 \mathrm{~g}, 3.88 \mathrm{mmol})$ also in THF $(20 \mathrm{~mL})$ at $-78^{\circ} \mathrm{C}$. The reaction mixture was warmed to room temperature and stirred overnight. The solvent was removed under vacuum and the residue obtained was dissolved in toluene $(30 \mathrm{~mL})$ and filtered. The filtrate was concentrated to $10 \mathrm{~mL}$ under reduced pressure and stored at $-20^{\circ} \mathrm{C}$ to yield analytically pure product of 2. Yield: $66 \%$ (0.68 g). M.p.: $161-164^{\circ} \mathrm{C} .{ }^{1} \mathrm{H}$ NMR $\left(400 \mathrm{MHz}, \mathrm{CDCl}_{3}\right): \delta 7.33\left(\mathrm{dd}, 1 \mathrm{H},{ }^{1} J_{\mathrm{PH}}=586 \mathrm{~Hz}\right.$, $\left.{ }^{3} J_{\mathrm{PH}}=3.1 \mathrm{~Hz}, \mathrm{PH}\right), 3.13\left(\mathrm{~d}, 1 \mathrm{H},{ }^{2} J_{\mathrm{PH}}=6.2 \mathrm{~Hz}, \mathrm{NH}\right)$, $1.44\left(\mathrm{~s}, 18 \mathrm{H}, \mu-\mathrm{N}^{t} \mathrm{Bu}\right), 1.16\left(\mathrm{~s}, 9 \mathrm{H},{ }^{t} \mathrm{BuNH}\right),{ }^{31} \mathrm{P}\left\{{ }^{1} \mathrm{H}\right\}$ $\operatorname{NMR}\left(162 \mathrm{MHz}, \mathrm{CDCl}_{3}\right): \delta 73.6(\mathrm{br} \mathrm{s}),-7.2\left(\mathrm{~d},{ }^{2} J_{\mathrm{PP}}=\right.$ $8.1 \mathrm{~Hz}, \mathrm{P}=\mathrm{O}) .{ }^{13} \mathrm{C}\left\{{ }^{1} \mathrm{H}\right\}: \delta 52.1\left(\mathrm{~d},{ }^{2} J_{\mathrm{PC}}=7.5 \mathrm{~Hz}\right), 51.9$ $\left(\mathrm{d},{ }^{2} J_{\mathrm{PC}}=14.5 \mathrm{~Hz}\right), 32.7\left(\mathrm{~d},{ }^{3} J_{\mathrm{PC}}=9.7 \mathrm{~Hz}\right), 31.5$ $\left(\mathrm{t},{ }^{3} J_{\mathrm{PC}}=4.6 \mathrm{~Hz}\right)$.

\subsection{Synthesis of cis- $\left\{\left({ }^{t} \mathrm{BuNH}\right) \mathrm{P}(\mathrm{Se})\left(\mu-\mathrm{N}^{t} \mathrm{Bu}\right)_{2} \mathrm{P}(\mathrm{O}) \mathrm{H}\right\}(\mathbf{3})$}

A mixture of $2(0.1 \mathrm{~g}, 0.341 \mathrm{mmol})$ and elemental selenium $(0.027 \mathrm{~g}, 0.342 \mathrm{mmol})$ in toluene $(20 \mathrm{~mL})$ was refluxed for $6 \mathrm{~h}$. The solution was cooled to room temperature, filtered through Celite and the solvent removed under vacuum to obtain $\mathbf{3}$ as an off-white crystalline solid. Analytically pure $\mathbf{3}$ was obtained by recrystallising the crude product from toluene. Yield: $98 \%$ (0.124 g). M.p.: 212-215 ${ }^{\circ} \mathrm{C}(\mathrm{dec})$. HRMS (Calcd. for $\mathrm{M}+\mathrm{H} \mathrm{C}_{12} \mathrm{H}_{29} \mathrm{~N}_{3} \mathrm{OP}_{2} \mathrm{Se}$ ): 374.1029. Found: 374.1045. Anal. Calcd. for $\mathrm{C}_{12} \mathrm{H}_{29} \mathrm{~N}_{3} \mathrm{OP}_{2} \mathrm{Se}$ : C, 38.71; H, 7.85; $\mathrm{N}, 11.29$. Found: $\mathrm{C}, 38.44 ; \mathrm{H}, 7.73 ; \mathrm{N}, 11.32$. IR $\left(\mathrm{KBr}, v / \mathrm{cm}^{-1}\right): 3165$ (br, m, N-H str.), 2396 (m, PH str.), 1262 (s), 1196 (s, P-O str.), 1071(s). ${ }^{1}$ H NMR $\left(400 \mathrm{MHz}, \mathrm{CDCl}_{3}\right): \delta 7.61\left(\mathrm{dd},{ }^{1} J_{\mathrm{PH}}=628 \mathrm{~Hz},{ }^{3} J_{\mathrm{PH}}=\right.$ $8.5 \mathrm{~Hz}, \mathrm{PH}, 1 \mathrm{H}), 3.66\left(\mathrm{~d},{ }^{2} J_{\mathrm{PH}}=15.0 \mathrm{~Hz}, \mathrm{NH}, 1 \mathrm{H}\right)$, $1.60\left(\mathrm{~s},{ }^{t} \mathrm{Bu}, 18 \mathrm{H}\right), 1.48$ (s, $\left.{ }^{t} \mathrm{Bu}, 9 \mathrm{H}\right),{ }^{31} \mathrm{P}\left\{{ }^{1} \mathrm{H}\right\} \mathrm{NMR}$ $\left(162 \mathrm{MHz}, \mathrm{CDCl}_{3}\right): \delta 20.9\left(\mathrm{~s},{ }^{1} J_{\mathrm{SeP}}=876 \mathrm{~Hz}, \mathrm{P}=\mathrm{Se}\right)$, $-12.4\left(\mathrm{~d},{ }^{2} J_{\mathrm{PP}}=22.7 \mathrm{~Hz}, \mathrm{P}=\mathrm{O}\right)$.

2.5 Synthesis of $\left[\left(\mathrm{PdCl}\left(\eta^{3}-\mathrm{C}_{3} \mathrm{H}_{5}\right)\right)_{2}\left\{\left({ }^{t} \mathrm{BuNH}\right) \mathrm{P}\left(\mu-\mathrm{N}^{t} \mathrm{Bu}\right)_{2}\right.\right.$ $\mathrm{P}(\mathrm{O}) \mathrm{H}\}]$ (4)

A solution of $\left[\mathrm{Pd}(\mu-\mathrm{Cl})\left(\eta^{3}-\mathrm{C}_{3} \mathrm{H}_{5}\right)\right]_{2} \quad(0.025 \mathrm{~g}$, $0.0683 \mathrm{mmol})$ in dichloromethane $(10 \mathrm{~mL})$ was added to a solution of $2(0.04 \mathrm{~g}, 0.1364 \mathrm{mmol})$ in the same solvent $(5 \mathrm{~mL})$ at room temperature. After $4 \mathrm{~h}$, the volume of the solvent was reduced to $2 \mathrm{~mL}$, the solution was layered with $4 \mathrm{~mL}$ of petroleum ether and kept at $-20^{\circ} \mathrm{C}$ for $24 \mathrm{~h}$ to obtain $\mathbf{4}$ as an analytically pure yellow solid. Yield: $83 \%(0.054 \mathrm{~g})$. M.p.: $245^{\circ} \mathrm{C}$ (dec). Anal. Calcd. for $\mathrm{C}_{15} \mathrm{H}_{34} \mathrm{ClN}_{3} \mathrm{OP}_{2} \mathrm{Pd}$ : C, 37.83; H, 7.20; N, 8.82. Found: C, 37.19; H, 6.60; N, 8.45. IR ( $\left.\mathrm{KBr}, v / \mathrm{cm}^{-1}\right)$ : 3219 (br, m, N-H str.), 2352 (m, P-H str.), 1265 (s), 1202 (s, P-O str.), 1062 (s). ${ }^{1} \mathrm{H}$ NMR $\left(400 \mathrm{MHz}, \mathrm{CDCl}_{3}\right): \delta 7.42\left(\mathrm{dd},{ }^{1} J_{\mathrm{PH}}=605.5 \mathrm{~Hz}\right.$, $\left.{ }^{3} J_{\mathrm{PH}}=7.5 \mathrm{~Hz}, \mathrm{PH}, 1 \mathrm{H}\right), 5.55(\mathrm{~m}, \mathrm{CH}, 1 \mathrm{H}), 5.26$ $\left(\mathrm{d},{ }^{2} J_{\mathrm{PH}}=28.8 \mathrm{~Hz}, \mathrm{NH}, 1 \mathrm{H}\right), 4.62(\mathrm{t}, J=8.4 \mathrm{~Hz}$, $\mathrm{CH}, 1 \mathrm{H}), 3.56(\mathrm{t}, J=13.6 \mathrm{~Hz}, \mathrm{CH}, 1 \mathrm{H}), 3.26(\mathrm{~d}$, $J=6.0 \mathrm{~Hz}, \mathrm{CH}, 1 \mathrm{H}), 2.74(\mathrm{~d}, J=12.0 \mathrm{~Hz}, \mathrm{CH}$, $1 \mathrm{H}), 1.54\left(\mathrm{~s},{ }^{t} \mathrm{Bu}, 9 \mathrm{H}\right), 1.43\left(\mathrm{~d}, J=13.4{ }^{t} \mathrm{Bu}, 18 \mathrm{H}\right)$. ${ }^{31} \mathrm{P}\left\{{ }^{1} \mathrm{H}\right\} \mathrm{NMR}\left(162 \mathrm{MHz}, \mathrm{CDCl}_{3}\right): \delta 54.9$ (s, P-Pd), $-13.4(\mathrm{~s}, \mathrm{P}=\mathrm{O}) .{ }^{31} \mathrm{P}$ NMR $\left(162 \mathrm{MHz}, \mathrm{CDCl}_{3}\right): \delta 54.9$ (s, P-Pd), $-13.4\left(\mathrm{~d},{ }^{1} J_{\mathrm{PH}}=606 \mathrm{~Hz}, \mathrm{P}=\mathrm{O}\right)$. MS (EI): $m / z=440.12[\mathrm{M}-\mathrm{Cl}]^{+}$.

\subsection{Synthesis of $\left[\left(\left(\eta^{6}-\text { p-cymene }\right) R u C l_{2}\right)_{2}\left\{\left({ }^{t} \mathrm{BuNH}\right)\right.\right.$ $\left.\left.P\left(\mu-N^{t} B u\right)_{2} P(O) H\right\}\right](5)$}

A solution of $\left[\mathrm{Ru}\left(\eta^{6}-p \text {-cymene }\right)(\mu-\mathrm{Cl}) \mathrm{Cl}\right]_{2}(0.024 \mathrm{~g}$, $0.0392 \mathrm{mmol})$ in dichloromethane $(10 \mathrm{~mL})$ was added to a solution of $2(0.023 \mathrm{~g}, 0.0784 \mathrm{mmol})$ in the same solvent $(10 \mathrm{~mL})$ at room temperature. The reaction mixture was stirred for $4 \mathrm{~h}$, the solvent volume was reduced to $2 \mathrm{~mL}$ under vacuum, and the solution layered with $4 \mathrm{~mL}$ of diethyl ether and kept in $-20^{\circ} \mathrm{C}$ for $24 \mathrm{~h}$ 
to afford analytically pure red crystals of $\mathbf{5}$. Yield: $77 \%$ (0.036 g). M.p.: $198^{\circ} \mathrm{C}$ (dec) Anal. Calcd. for $\mathrm{C}_{22} \mathrm{H}_{43}$ $\mathrm{Cl}_{2} \mathrm{~N}_{3} \mathrm{OP}_{2} \mathrm{Ru} \cdot 2 \mathrm{CH}_{2} \mathrm{Cl}_{2}$ : C, 37.47; H, 6.16; N, 5.46. Found: C, 37.23; H, 6.10; N, 5.64. ${ }^{1} \mathrm{H}$ NMR $(400 \mathrm{MHz}$, $\left.\mathrm{CDCl}_{3}\right): \delta 7.84\left(\mathrm{dd},{ }^{1} J_{\mathrm{PH}}=604 \mathrm{~Hz},{ }^{3} J_{\mathrm{PH}}=11.2 \mathrm{~Hz}\right.$, $\mathrm{PH}, 1 \mathrm{H}), 5.66\left(\mathrm{~d},{ }^{3} J_{\mathrm{HH}}=6.0 \mathrm{H}, \mathrm{CH}, 2 \mathrm{H}\right), 5.35(\mathrm{~s}$, $\left.\mathrm{CH}_{2} \mathrm{Cl}_{2}, 4 \mathrm{H}\right), 5.08\left(\mathrm{~d},{ }^{3} J_{\mathrm{HH}}=6.0 \mathrm{~Hz}, \mathrm{CH}, 2 \mathrm{H}\right), 4.09$ $\left(\mathrm{d},{ }^{2} J_{\mathrm{PH}}=22.0 \mathrm{~Hz}, \mathrm{NH}, 1 \mathrm{H}\right), 3.13\left(\mathrm{p},{ }^{3} J_{\mathrm{HH}}=6.8 \mathrm{~Hz}\right.$, $\mathrm{CH}, 1 \mathrm{H}), 2.18\left(\mathrm{~s}, \mathrm{CH}_{3}, 3 \mathrm{H}\right) 1.63\left(\mathrm{~s},{ }^{t} \mathrm{Bu}, 18 \mathrm{H}\right), 1.38$ $\left(\mathrm{s},{ }^{t} \mathrm{Bu}, 9 \mathrm{H}\right), 1.36\left(\mathrm{~d},{ }^{3} J_{\mathrm{HH}}=6.8 \mathrm{~Hz}, \mathrm{C}\left(\mathrm{CH}_{3}\right)_{2}, 6 \mathrm{H}\right)$. ${ }^{31} \mathrm{P}\left\{{ }^{1} \mathrm{H}\right\} N M R\left(162 \mathrm{MHz}, \mathrm{CDCl}_{3}\right): \delta 62.7\left(\mathrm{~d},{ }^{2} J_{\mathrm{PP}}=\right.$ $16.8 \mathrm{~Hz}, \mathrm{P}-\mathrm{Pd}),-6.4(\mathrm{~d}, \mathrm{P}=\mathrm{O})$. MS (EI): $m / z=564.2$ $[\mathrm{M}-\mathrm{Cl}]^{+}$.

\subsection{Synthesis of $\left[P d C l_{2}\left\{\left({ }^{t} B u N H\right) P\left(\mu-N^{t} B u\right)_{2}\right.\right.$ $\mathrm{P}(\mathrm{O}) \mathrm{HJ}_{2}$ ] (6)}

A solution of $\mathrm{Pd}(\mathrm{COD}) \mathrm{Cl}_{2}(0.0204 \mathrm{~g}, 0.0716 \mathrm{mmol})$ in dichloromethane $(5 \mathrm{~mL})$ was added to a solution of 2 $(0.042 \mathrm{~g}, 0.1432 \mathrm{mmol})$ in the same solvent $(5 \mathrm{~mL})$ at room temperature. The resultant yellow solution was stirred for $4 \mathrm{~h}$ and all the volatiles were removed under reduced pressure to yield $\mathbf{6}$ as yellow crystalline solid. The complex $\mathbf{6}$ was recrystallized from a mixture of dichloromethane and petroleum ether to obtain analytically pure crystals. Yield: 84\% (0.046 g). M.p.: 230$232^{\circ} \mathrm{C}$. Anal. Calcd. for $\mathrm{C}_{24} \mathrm{H}_{58} \mathrm{Cl}_{2} \mathrm{~N}_{6} \mathrm{O}_{2} \mathrm{P}_{4} \mathrm{Pd}$ : C, 37.73; H, 7.65; N, 11.00. Found: C, 37.68; H, 7.34; N, 10.89 . IR $\left(\mathrm{KBr}, v / \mathrm{cm}^{-1}\right): 3242$ (m, NH, str), $2972(\mathrm{~m}), 2392$ (s, PH, str), 1266 (m), 1200 (m, P=O, str). ${ }^{1} \mathrm{H}$ NMR $\left(400 \mathrm{MHz}, \mathrm{CDCl}_{3}\right): \delta 7.62\left(\mathrm{dt},{ }^{1} J_{\mathrm{PH}}=651 \mathrm{~Hz}, J=\right.$ $4.4 \mathrm{~Hz}, \mathrm{PH}, 2 \mathrm{H}), 7.59\left(\mathrm{dt},{ }^{1} J_{\mathrm{PH}}=650 \mathrm{~Hz}, J=4.4 \mathrm{~Hz}\right.$, $\mathrm{PH}, 2 \mathrm{H}), 5.41(\mathrm{t}, J=14.4 \mathrm{~Hz}, \mathrm{NH}, 2 \mathrm{H}), 5.24(\mathrm{t}$, $J=14.4 \mathrm{~Hz}, \mathrm{NH}, 2 \mathrm{H}), 1.62\left(\mathrm{~s},{ }^{t} \mathrm{Bu}, 72 \mathrm{H}\right), 1.45(\mathrm{~s}$, $\left.{ }^{t} \mathrm{Bu}, 36 \mathrm{H}\right) .{ }^{31} \mathrm{P}\left\{{ }^{1} \mathrm{H}\right\} \mathrm{NMR}\left(162 \mathrm{MHz}, \mathrm{CDCl}_{3}\right): \delta 40.92$ (unresolved t, P-Pd), 40.86 (unresolved t, P-Pd), -6.5 $(\mathrm{t}, J=4 \mathrm{~Hz}, \mathrm{P}=\mathrm{O}),-6.8(\mathrm{~s}, J=5.9 \mathrm{~Hz}, \mathrm{P}=\mathrm{O}) .{ }^{31} \mathrm{P}$ NMR $\left(162 \mathrm{MHz}, \mathrm{CDCl}_{3}\right): \delta 40.9$ (s, P-Pd), -6.5 (d, $\left.{ }^{1} J_{\mathrm{PH}}=652 \mathrm{~Hz}, \mathrm{P}=\mathrm{O}\right),-6.8\left(\mathrm{~d},{ }^{1} J_{\mathrm{PH}}=651 \mathrm{~Hz}, \mathrm{P}=\mathrm{O}\right)$. MS (EI): $m / z=765.2[\mathrm{M}+\mathrm{H}]^{+}$.

\subsection{Synthesis of $\left[\mathrm{PtCl}_{2}\left\{\left({ }^{t} \mathrm{BuNH}\right) \mathrm{P}\left(\mu-\mathrm{N}^{t} \mathrm{Bu}\right)_{2}\right.\right.$ $\left.\mathrm{P}(\mathrm{O}) \mathrm{H}_{2}\right]$ (7)}

A dichloromethane solution $(5 \mathrm{~mL})$ of $\mathrm{Pt}(\mathrm{COD}) \mathrm{Cl}_{2}$ $(0.0191 \mathrm{~g}, 0.0511 \mathrm{mmol})$ was added to a solution of 2 $(0.03 \mathrm{~g}, 0.1023 \mathrm{mmol})$ in the same solvent $(5 \mathrm{~mL})$ at room temperature. The reaction mixture was stirred for $4 \mathrm{~h}$ and all the volatiles were removed under reduced pressure to obtain an off-white residue. The residue obtained was re-dissolved in dichloromethane $(2 \mathrm{~mL})$, layered with petroleum ether $(4 \mathrm{~mL})$ and stored at $-20^{\circ} \mathrm{C}$ for $24 \mathrm{~h}$ to obtain 7 as analytically pure white crystalline solid. Yield: $81 \%$ (0.035 g). M.p.: $>275^{\circ} \mathrm{C}$. Anal. Calcd. for $\mathrm{C}_{24} \mathrm{H}_{58} \mathrm{Cl}_{2} \mathrm{~N}_{6} \mathrm{O}_{2} \mathrm{P}_{4} \mathrm{Pt} \cdot \mathrm{CH}_{2} \mathrm{Cl}_{2}$ : C, 32.03; H, 6.45; N, 8.96. Found: C, 32.11; H, 6.37; N, 8.61. IR (KBr, v/ $\left.\mathrm{cm}^{-1}\right): 3254(\mathrm{~m}, \mathrm{NH}, \mathrm{str}), 2971(\mathrm{~m}), 2390$ (s, PH, str), 1266 (m), 1203 (m, P=O, str). ${ }^{1} \mathrm{H}$ NMR $\left(400 \mathrm{MHz}, \mathrm{CDCl}_{3}\right): \delta 7.54\left(\mathrm{dt},{ }^{1} J_{\mathrm{PH}}=650 \mathrm{~Hz},{ }^{3} J_{\mathrm{PH}}=\right.$ $4.4 \mathrm{~Hz}, \mathrm{PH}, 2 \mathrm{H}), 7.51\left(\mathrm{dt},{ }^{1} J_{\mathrm{PH}}=648 \mathrm{~Hz},{ }^{3} J_{\mathrm{PH}}=\right.$ $4.4 \mathrm{~Hz}, \mathrm{PH}, 2 \mathrm{H}), 5.51\left(\mathrm{~s}, \mathrm{CH}_{2} \mathrm{Cl}_{2}, 2 \mathrm{H}\right), 5.46(\mathrm{t}, J=$ $13.2 \mathrm{~Hz}, \mathrm{NH}, 2 \mathrm{H}), 5.29$ (t, $J=13.2 \mathrm{~Hz}, \mathrm{NH}, 2 \mathrm{H})$, $1.62\left(\mathrm{~s},{ }^{t} \mathrm{Bu}, 72 \mathrm{H}\right), 1.46$ (s, $\left.{ }^{t} \mathrm{Bu}, 36 \mathrm{H}\right) .{ }^{31} \mathrm{P}\left\{{ }^{1} \mathrm{H}\right\} \mathrm{NMR}$ $\left(162 \mathrm{MHz}, \mathrm{CDCl}_{3}\right): \delta 36.7\left(\mathrm{t}, J=6.5 \mathrm{~Hz},{ }^{1} J_{\mathrm{PtP}}=\right.$ $3379 \mathrm{~Hz}, \mathrm{P}-\mathrm{Pt}),-3.9\left(\mathrm{t}, J=8.3 \mathrm{~Hz},{ }^{3} J_{\mathrm{PtP}}=77.1 \mathrm{~Hz}\right.$, $\mathrm{P}=\mathrm{O}),-4.4\left(\mathrm{t}, J=6.2 \mathrm{~Hz},{ }^{3} J_{\mathrm{PtP}}=83.3 \mathrm{~Hz}, \mathrm{P}=\mathrm{O}\right)$. ${ }^{31} \mathrm{P}$ NMR $\left(162 \mathrm{MHz}, \mathrm{CDCl}_{3}\right): \delta 36.7$ (br s, ${ }^{1} J_{\mathrm{PtP}}=$ $3382 \mathrm{~Hz}, \mathrm{P}-\mathrm{Pt}),-3.9\left(\mathrm{~m},{ }^{1} \mathrm{~J}_{\mathrm{PH}}=648 \mathrm{~Hz}, \mathrm{P}=\mathrm{O}\right),-4.4$ $(\mathrm{m}, \mathrm{P}=\mathrm{O}) .{ }^{195} \mathrm{Pt}\left\{{ }^{1} \mathrm{H}\right\} \mathrm{NMR}\left(107.5 \mathrm{MHz}, \mathrm{CDCl}_{3}\right): \delta-$ $3872\left(\mathrm{t},{ }^{1} J_{\mathrm{PtP}}=3381 \mathrm{~Hz}\right),-3859\left(\mathrm{t},{ }^{1} J_{\mathrm{PtP}}=3402 \mathrm{~Hz}\right)$. MS (EI): $m / z=875.25[\mathrm{M}+\mathrm{Na}]^{+}$.

\section{$2.9 \quad$ X-ray Crystallography}

A crystal of the compound 5 suitable for X-ray crystal analysis was mounted on a Cryoloop with a drop of Paratone oil and placed in the cold nitrogen stream of the Kryoflex attachment of the Bruker APEX CCD diffractometer. A full sphere of data was collected using 3 sets of 400 frames, each of width $0.5^{\circ}$ in $\omega$, collected at $\varphi=0.00,90.00$ and $180.00^{\circ}$ and 2 sets of 800 frames, each of width $0.45^{\circ}$ in $\varphi$, collected at $\omega=-30.00$ and $210.00^{\circ}$ using the $A P E X 2^{39}$ program suite. A crystal of 7 was mounted on a glass fibre using epoxy glue and placed on a Rigaku Saturn724 CCD diffractometer equipped with graphite-monochromated Mo-K $\alpha$ radiation $(\lambda=0.71073 \AA)$. For $\mathbf{5}$, the raw data were reduced to $\mathrm{F}^{2}$ values using the SAINT software, ${ }^{39}$ while for 7, the images were processed with the CrystalClear program (Expert 2.1 b24). Multiple measurements of equivalent reflections provided the basis for an empirical absorption correction as well as a correction for any crystal deterioration during the data collection $\left(S A D A B S^{39}\right)$. Both the structures were solved by direct methods $\left(S H E L X S^{40}\right)$ and refined by full-matrix leastsquares procedures on $\mathrm{F}^{2}$ using SHELXL ${ }^{40}$ (SHELXTL program package. ${ }^{39}$ Hydrogen atoms attached to carbon were placed in calculated positions and included as riding contributions with isotropic displacement parameters tied to those of the attached non-hydrogen atoms. Those attached to nitrogen were placed in locations derived from a difference map and also included as riding contributions as for the others. The isotropic thermal parameters of the hydrogen atoms were fixed at 1.2 times that of the corresponding carbon for phenyl hydrogen and 1.5 times for $\mathrm{C}\left(\mathrm{CH}_{3}\right)_{3}$. Crystallographic 
data (excluding structures factors) for the structures reported in this paper have been deposited with the Cambridge Crystallographic Data Centre as supplementary publication no. CCDC 1000229 (compound 5) and 1000230 (compound 7).

\section{Results and Discussion}

Hydrolysis of cis- $\left\{\mathrm{ClP}\left(\mu-\mathrm{N}^{t} \mathrm{Bu}\right)_{2} \mathrm{P}\left(\mathrm{NH}^{t} \mathrm{Bu}\right)\right\}$ (1) with one equivalent of degassed water in the presence of triethylamine at $-78^{\circ} \mathrm{C}$ resulted in the formation of a mixed-valent derivative cis- $\left\{\left({ }^{t} \mathrm{BuNH}\right) \mathrm{P}(\mu\right.$ $\left.\left.\mathrm{N}^{t} \mathrm{Bu}\right)_{2} \mathrm{P}(\mathrm{O}) \mathrm{H}\right\}(2)$, as shown in scheme 1. Because of the interference of adventitious water, $\mathbf{2}$ is an undesired product in many reactions involving $\mathbf{1}$. The compound $\mathbf{2}$ is air and moisture stable and obtained as an analytically pure white solid after recrystallisation from toluene. The reaction of $\mathbf{2}$ with elemental selenium in toluene resulted in the formation of the monoselenide, trans $-\left\{\left({ }^{t} \mathrm{BuNH}\right) \mathrm{P}(\mathrm{Se})\left(\mu-\mathrm{N}^{t} \mathrm{Bu}\right)_{2} \mathrm{P}(\mathrm{O}) \mathrm{H}\right\}(3)$ along with a small amount of cis isomer 3a. The ${ }^{31} \mathrm{P}\left\{{ }^{1} \mathrm{H}\right\}$ NMR spectrum of $\mathbf{3}$ showed two doublets at $20.9 \mathrm{ppm}$ and $-12.4 \mathrm{ppm}$ with a ${ }^{2} J_{\mathrm{PP}}$ coupling of $22.7 \mathrm{~Hz}{ }^{41,42}$ The signal at $20.9 \mathrm{ppm}$ having characteristic selenium satellite peaks with a ${ }^{1} J_{\mathrm{SeP}}$ coupling of $876 \mathrm{~Hz}$ was assigned to the $\mathrm{P}(\mathrm{Se})$ centre. The ${ }^{1} \mathrm{H}$ NMR spectrum of $\mathbf{3}$ showed a doublet of doublets for the $\mathrm{PH}$ proton with a large ${ }^{1} J_{\mathrm{PH}}$ coupling $(628 \mathrm{~Hz})$ and a relatively small ${ }^{3} J_{\mathrm{PH}}$ coupling $(8.5 \mathrm{~Hz})$. The coupling constants are larger than those observed for $2\left({ }^{1} J_{\mathrm{PH}}=586 \mathrm{~Hz}\right.$ and $\left.{ }^{3} J_{\mathrm{PH}}=3.1 \mathrm{~Hz}\right)$. The large ${ }^{1} J_{\mathrm{PH}}$ coupling in the ${ }^{1} \mathrm{H}$ NMR spectrum of $\mathbf{3}$ confirms the presence of the $\mathrm{P}(\mathrm{O}) \mathrm{H}$ rather than the $\mathrm{POH}$ tautomer in solution. The structure and molecular composition of compound $\mathbf{3}$ was further confirmed by mass spectrometry and elemental analysis.
The reaction of two equivalent of 2 with $[\mathrm{Pd}(\mu-\mathrm{Cl})$ $\left.\left(\eta^{3}-\mathrm{C}_{3} \mathrm{H}_{5}\right)\right]_{2}$ in dichloromethane gave $\left[\left(\eta^{3}-\mathrm{C}_{3} \mathrm{H}_{5}\right) \mathrm{PdCl}\right.$ $\left.\left\{\left({ }^{t} \mathrm{BuNH}\right) \mathrm{P}\left(\mu-\mathrm{N}^{t} \mathrm{Bu}\right)_{2} \mathrm{P}(\mathrm{O}) \mathrm{H}\right\}\right](4)$. The ${ }^{31} \mathrm{P}\left\{{ }^{1} \mathrm{H}\right\} \mathrm{NMR}$ spectrum of 4 recorded in $\mathrm{CDCl}_{3}$ showed two singlets for coordinated phosphorus and $\mathrm{P}(\mathrm{O})$ atoms, at 54.9 and $-13.4 \mathrm{ppm}$, respectively. The spectral assignments for compound 4 were confirmed by a proton-coupled ${ }^{31} \mathrm{P}$ NMR spectrum in which the signal at $-13.4 \mathrm{ppm}$ splits into a doublet with a ${ }^{1} J_{\mathrm{PH}}$ coupling of $606 \mathrm{~Hz}$. The ${ }^{1} \mathrm{H}$ NMR spectrum confirms the presence of a coordinated allyl group. All the five protons of the allyl fragment

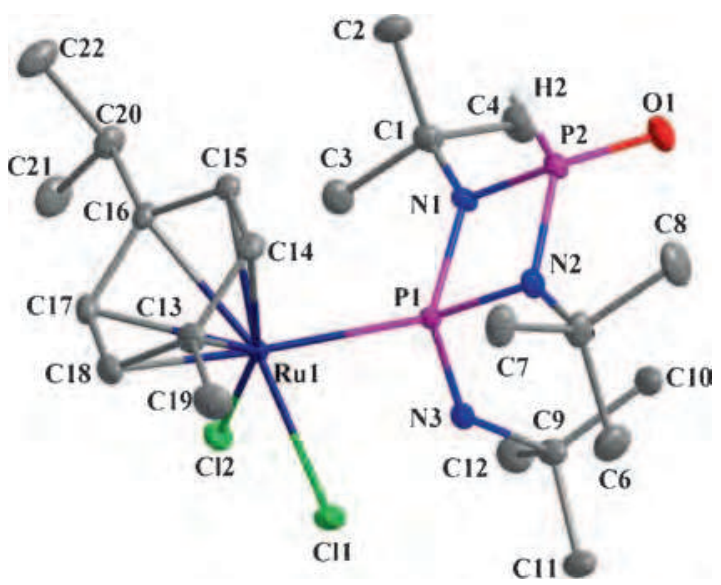

Figure 1. The molecular structure of $\left[\left(\eta^{6}-p\right.\right.$-cymene $)$ $\left.\mathrm{RuCl}_{2}\left\{\left({ }^{t} \mathrm{BuNH}\right) \mathrm{P}\left(\mu-\mathrm{N}^{t} \mathrm{Bu}\right)_{2} \mathrm{P}(\mathrm{O}) \mathrm{H}\right\}\right] \quad$ (5). All hydrogen atoms except $\mathrm{H}(\mathrm{P})$ and lattice solvent molecules are omitted for clarity. Thermal ellipsoids are drawn at the 50\% probability level. Selected bond distances [Å]: Ru1-Cl1, 2.4224(12); Ru1-Cl2， 2.4154(12); Ru1-P1， 2.3892(12); P2-O1, 1.4736(16); P1-N2, 1.7358(19); P1-N3, 1.6320(17); $\mathrm{P} 2-\mathrm{N} 1,1.6627(18) ; \mathrm{P} 2-\mathrm{N} 2,1.6754(18)$. Selected bond angles [ ${ }^{\circ}$ ]: Cl1-Ru1-Cl2, 86.37(1); Cl1-Ru1-P1, 84.54(2); Cl2-Ru1-P1, 88.26(1); N1-P1-N2, 81.20(8); N1-P2-N2, 84.83(8).

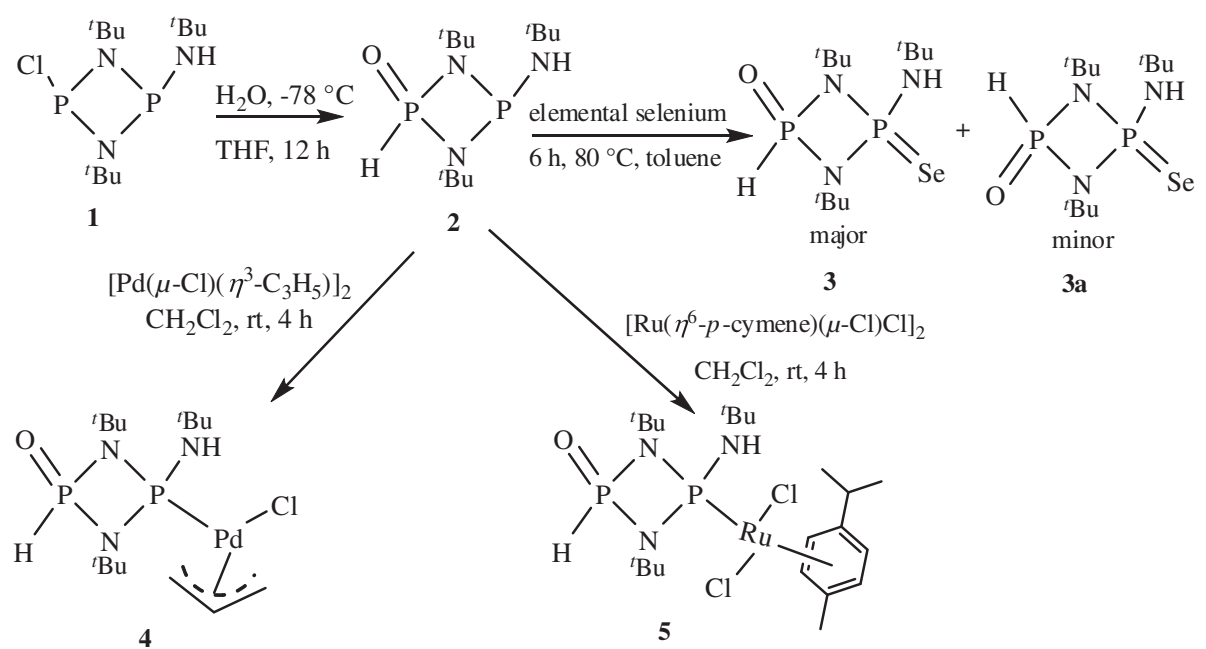

Scheme 1. Synthesis and reactivity of $c i s-\left\{\left({ }^{t} \mathrm{BuNH}\right) \mathrm{P}\left(\mu-\mathrm{N}^{t} \mathrm{Bu}\right)_{2} \mathrm{P}(\mathrm{O}) \mathrm{H}\right\}($ 2). 
appear distinctly in the ${ }^{1} \mathrm{H}$ NMR spectrum of 4 . The ${ }^{1} \mathrm{H}$ NMR data indicate the allyl group $\left(\eta^{3}-\mathrm{C}_{3} \mathrm{H}_{5}\right)$ is rigidly coordinated to the metal centre and all the four terminal syn and anti protons remain non-equivalent on NMR time scale.

The reaction of 2 with $\left[\mathrm{Ru}\left(\eta^{6}-p \text {-cymene }\right)(\mu-\mathrm{Cl}) \mathrm{Cl}\right]_{2}$ afforded $\left[\left(\left(\eta^{6}-p\right.\right.\right.$-cymene $\left.) \mathrm{RuCl}_{2}\right)\left\{\left({ }^{t} \mathrm{BuNH}\right) \mathrm{P}\left(\mu-\mathrm{N}^{t} \mathrm{Bu}\right)_{2}\right.$ $\mathrm{P}(\mathrm{O}) \mathrm{H}\}]$ (5) in moderate yield. The ${ }^{31} \mathrm{P}\left\{{ }^{1} \mathrm{H}\right\}$ NMR spectrum of $\mathbf{5}$ showed two doublets centered at 62.7 and $-6.4 \mathrm{ppm}$, with a ${ }^{2} J_{\mathrm{PP}}$ coupling of $16.8 \mathrm{~Hz}$. The mass spectrum of $\mathbf{5}$ showed base peak at 564.2 corresponding to the $[\mathrm{M}-\mathrm{Cl}]^{+}$ion. Further, the structure of $\mathbf{5}$ is established by a single-crystal X-ray diffraction study.

Slow diffusion of petroleum ether into a chloroform solution of $\mathbf{5}$ led to the formation of crystals suitable for X-ray diffraction studies. ${ }^{43}$ The coordination geometry around the ruthenium center in $\mathbf{5}$ is typical pseudooctahedral (figure 1) with a three-legged piano-stool arrangement having ligand $\mathbf{2}$ acting as a monodentate ligand. The $\mathrm{Ru}-\mathrm{P} 1$ bond distance is $2.3892(12) \AA$ and $\mathrm{Ru}-\mathrm{C}$ bond distances range from 2.205(2) to 2.262(2) $\AA$ with an average bond distance of $2.236 \AA$, which is slightly longer than that of $\left[\left(\eta^{6}-p\right.\right.$-cymene $) \mathrm{RuCl}_{2}\{\{(o-$ $\left.\left.\left.\left.\mathrm{MeOC}_{6} \mathrm{H}_{4} \mathrm{O}\right) \mathrm{P}\left(\mu-\mathrm{N}^{t} \mathrm{Bu}\right)\right\}_{2}\right\} \mathrm{AuCl}\right]{ }^{44}$ The P2-O1 bond distance in $\mathbf{5}[1.474(2) \AA]$ is similar to that of $\mathbf{2}$ $[1.468(2) \AA]$, whereas the $\mathrm{P} 2-\mathrm{H} 2$ bond distance in $\mathbf{5}$ $[1.26(2) \AA]$ is shorter than that of the free ligand 2 $[1.35(2) \AA] .{ }^{32}$

The steric and electronic aspects of the coordinating ligands dictate the conformations of $d^{8}$ square planar complexes. The bulky ligands generally confer trans configuration, whereas the strong $\sigma$-donor ligands impose cis conformation around the metal center due to the trans influence. ${ }^{45-47}$ The reaction of 2 with $\mathrm{M}(\mathrm{COD}) \mathrm{Cl}_{2}(\mathrm{M}=\mathrm{Pd}$ and $\mathrm{Pt})$ can give six possible conformational and geometrical isomers, as both the cyclodiphosphazane as well as the metal center can adopt cis and trans conformations (chart 2). The treatment of 2 with $\mathrm{M}(\mathrm{COD}) \mathrm{Cl}_{2}(\mathrm{M}=\mathrm{Pd}$ and $\mathrm{Pt})$ in 2:1 ratio in dichloromethane at room temperature resulted in the formation of $\left[\mathrm{MCl}_{2}\left\{\left({ }^{t} \mathrm{BuNH}\right) \mathrm{P}\left(\mu-\mathrm{N}^{t} \mathrm{Bu}\right)_{2} \mathrm{P}(\mathrm{O}) \mathrm{H}\right\}_{2}\right](6$ $\mathrm{M}=\mathrm{Pd} ; 7 \mathrm{M}=\mathrm{Pt}$ ) as shown in scheme 2. In both the complexes, the metal centres adopt trans geometry as established by the X-ray analysis of 7 . The microanalytical data of both 6 and 7 support 1:2 ratio of metal to ligand in the isolated products. The evidence for the formation of complexes also comes from mass spectral data, where both $\mathbf{6}$ and 7 show the molecular ion peaks, at $765.2[\mathrm{M}+\mathrm{H}]^{+}$and $875.2[\mathrm{M}+\mathrm{Na}]^{+}$, respectively. To assign the geometry of the cyclodiphosphazanes in $\mathbf{6}$ and 7, both 1D and 2D NMR studies were carried out.

The ${ }^{31} \mathrm{P}\left\{{ }^{1} \mathrm{H}\right\}$ and ${ }^{1} \mathrm{H}$ NMR spectra of complexes 6 and 7 recorded in $\mathrm{CDCl}_{3}$ at room temperature are similar, which confirm that the structures of both the complexes in solution are essentially the same. The ${ }^{31} \mathrm{P}\left\{{ }^{1} \mathrm{H}\right\} \mathrm{NMR}$ spectrum of the palladium complex 6 shows two unresolved triplets centred at 40.92 and $40.86 \mathrm{ppm}$ and two set of triplets centered at -6.5 and $-6.8 \mathrm{ppm}$ with couplings of 4.0 and $5.9 \mathrm{~Hz}$ in a $\sim 2: 3$ ratio, respectively, as shown in figure 2 . The ${ }^{31} \mathrm{P}\left\{{ }^{1} \mathrm{H}\right\}$ NMR spectrum of platinum complex 7 showed three triplets at $36.7,-3.9$ and $-4.4 \mathrm{ppm}$. The signal at $36.7 \mathrm{ppm}$ with a ${ }^{1} J_{\mathrm{PtP}}$ coupling of $3379 \mathrm{~Hz}$ was assigned to the coordinated phosphorus. In the ${ }^{1} \mathrm{H}$ coupled ${ }^{31} \mathrm{P}$ NMR spectra of $\mathbf{6}$ and 7, only the upfield signals split into two sets of resonances with large ${ }^{1} J_{\mathrm{PH}}$ values. This observation confirms that the upfield signals are due to the phosphorus atom directly attached to hydrogen. Based on ${ }^{31} \mathrm{P}$ NMR integration, it is clear that the two products in $\mathbf{6}$ exist in $\sim 3: 2$ ratios. No interconversion was observed on keeping the solution of complex 6 in $\mathrm{CDCl}_{3}$ for $24 \mathrm{~h}$ at room temperature.

The ${ }^{1} \mathrm{H}$ NMR spectrum of $\mathbf{6}$ showed complex splitting patterns due to the presence of two isomers. Two overlapping doublets of triplets centered at 7.62 and $7.59 \mathrm{ppm}$ are observed for the PH protons $\left(\left|{ }^{1} J_{\mathrm{PH}}\right|=\right.$ $651 \mathrm{~Hz},|J|=4.4 \mathrm{~Hz})$, the $\mathrm{NH}$ protons appear as triplets centred at 5.41 and $5.24 \mathrm{ppm}(\sim 3: 2$ ratio) with a coupling of $|J|=14.4 \mathrm{~Hz}$. The observed multiplicity is probably due to the long range coupling between $\mathrm{NH}$ and $\mathrm{PH}$ protons. The ${ }^{1} \mathrm{H}-{ }^{1} \mathrm{H}$ COSY spectrum indicates that the triplet at $5.41 \mathrm{ppm}(\mathrm{NH})$ is correlated with the doublet of triplets at $7.62 \mathrm{ppm}(\mathrm{PH})$. Similarly, the triplet at $5.24 \mathrm{ppm}(\mathrm{NH})$ is correlated with the doublet of triplets at $7.59 \mathrm{ppm}(\mathrm{PH})$. Furthermore, in the ${ }^{31} \mathrm{P}-$ ${ }^{1} \mathrm{H}$ HSQC experiment (figure 3), the triplets at 7.62<smiles>[3H][Y1](P)(Cl)Cl</smiles>

cis<smiles>[3H][W](P)(Cl)Cl</smiles>

trans

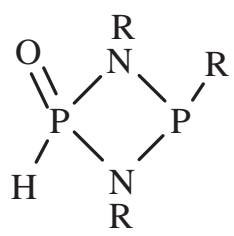

cis

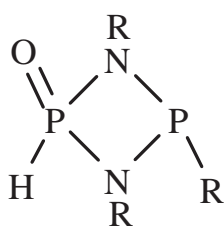

trans

Chart 2. Possible isomers of 6 and 7. 


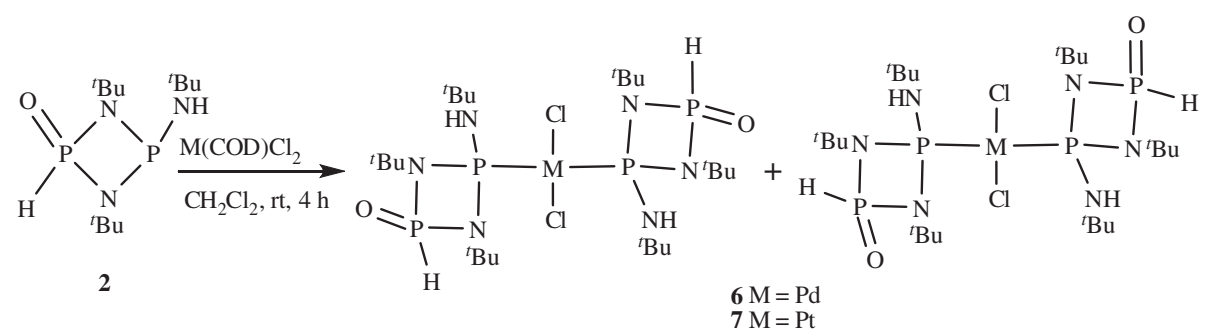

Scheme 2. $\mathrm{Pd}(\mathrm{II})$ and $\mathrm{Pt}(\mathrm{II})$ complexes of $c i s-\left\{\left({ }^{t} \mathrm{BuNH}\right) \mathrm{P}\left(\mu-\mathrm{N}^{t} \mathrm{Bu}\right)_{2} \mathrm{P}(\mathrm{O}) \mathrm{H}\right\}$ (2).
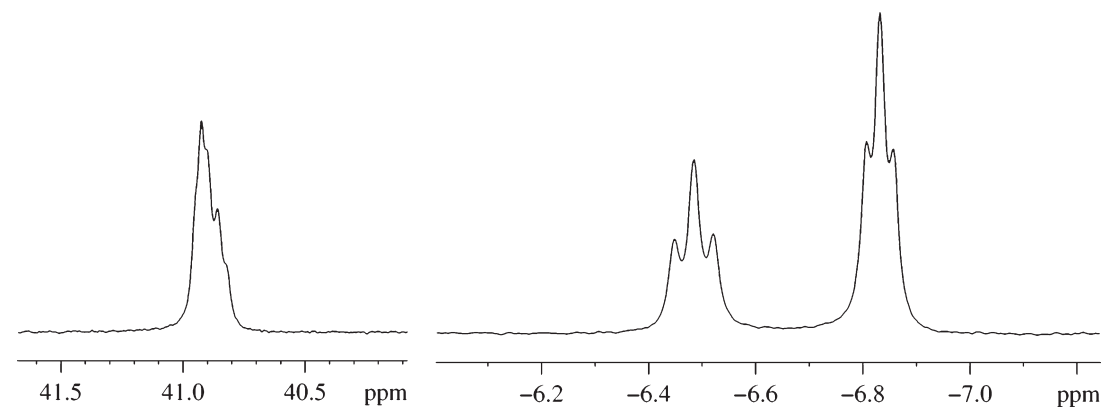

Figure 2. The ${ }^{31} \mathrm{P}\left\{{ }^{1} \mathrm{H}\right\} \mathrm{NMR}$ spectrum $\left[\mathrm{PdCl}_{2}\left\{\left({ }^{t} \mathrm{BuNH}\right) \mathrm{P}\left(\mu-\mathrm{N}^{t} \mathrm{Bu}\right)_{2} \mathrm{P}(\mathrm{O}) \mathrm{H}\right\}_{2}\right](\mathbf{6})$.

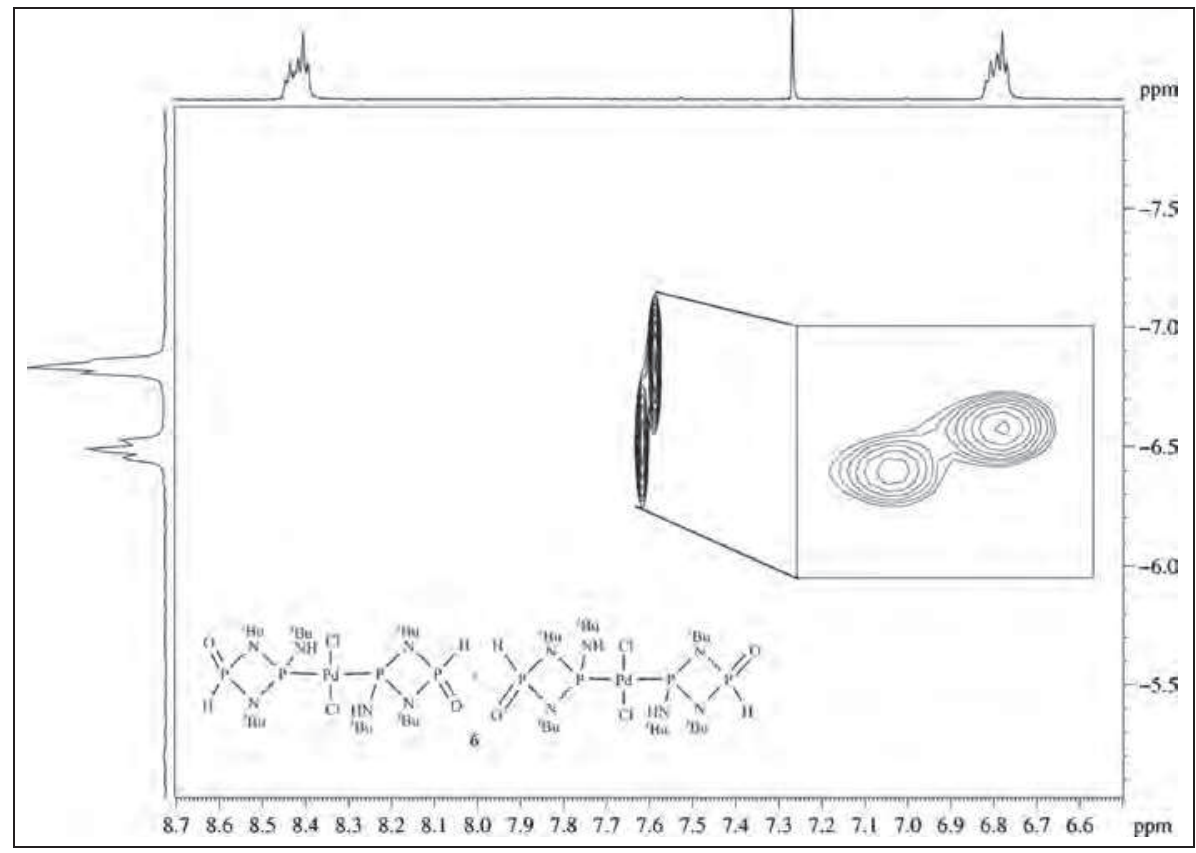

Figure 3. ${ }^{31} \mathrm{P}-{ }^{1} \mathrm{H}$ HSQC spectrum of 6 recorded in $\mathrm{CDCl}_{3}$.

and $7.59 \mathrm{ppm}$ showed correlation with the phosphorus signals at -6.5 and $-6.8 \mathrm{ppm}$, respectively. The ${ }^{195} \mathrm{Pt}\left\{{ }^{1} \mathrm{H}\right\}$ NMR spectrum of 7 showed two overlapping triplets with similar coupling constants, at $-3872\left({ }^{1} J_{\mathrm{PtP}}\right.$ $=3380 \mathrm{~Hz})$ and $-3859\left({ }^{1} J_{\mathrm{PtP}}=3402 \mathrm{~Hz}\right)$. This obeservation clearly indicates the presence of two different species in solution.

The X-ray structure of $\mathbf{7}$ confirms the trans geometry around the square planar platinum centre as shown in figure 4 . Both the cyclodiphosphazane rings in 7 assume the trans conformation in the solid state. Because of the steric bulk, the vector $\mathrm{Cl1}-\mathrm{Pt} 1-\mathrm{Cl} 1^{\mathrm{i}}$ is tilted away from exocyclic nitrogen, and the acute bond angle $\mathrm{Cl1}-$ $\mathrm{Pt} 1-\mathrm{P} 1$ is $87.10(2)^{\circ}$. The Pt1-P1 [2.3062(8) $\left.\AA\right]$ and Pt1Cl1 [2.3116(7) $\AA]$ bond distances for 7 are comparable to the $\mathrm{Pt}-\mathrm{P}[2.2447(13) \AA]$ and $\mathrm{Pt}-\mathrm{Cl}[2.3254(15) \AA]$ bond lengths of the complex $\left[\left(\mathrm{PtCl}_{2}\right)_{2}\left\{{ }^{t} \mathrm{BuNP}\left(\mathrm{OC}_{6}\right.\right.\right.$ $\left.\left.\mathrm{H}_{4} \mathrm{PPh}_{2}-\mathrm{O}\right)\right\}_{2}{ }^{48}$ The $\mathrm{P}-\mathrm{O}$ bond lengths in 7 [1.467(2) $\AA$ ] 


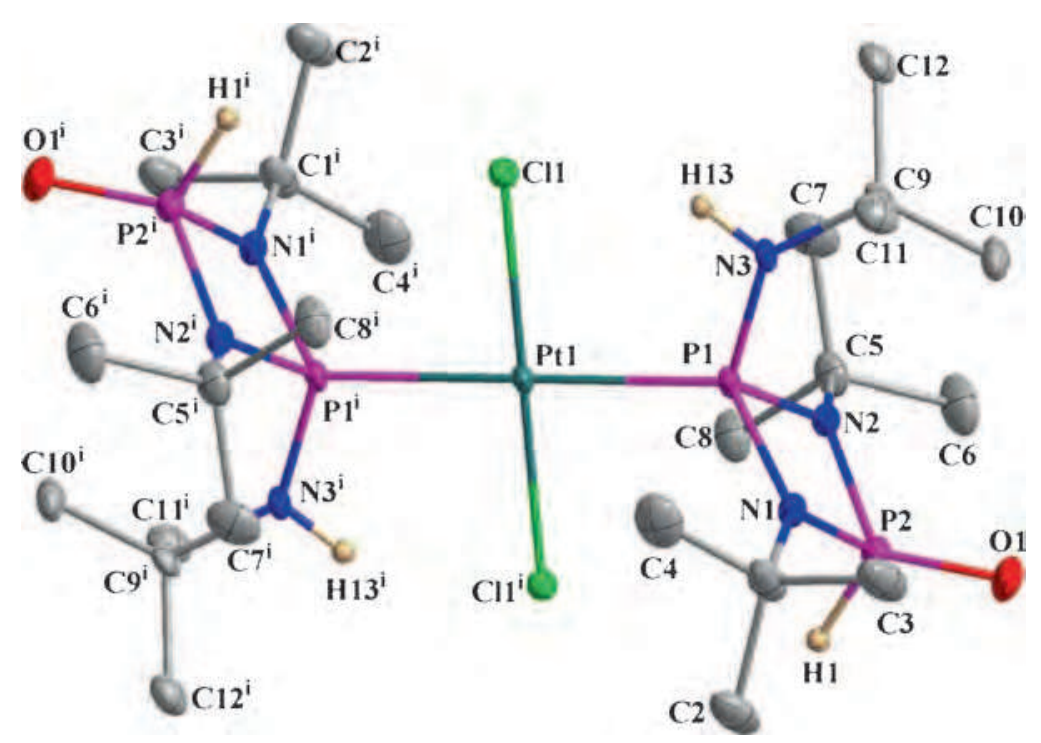

Figure 4. The molecular structure of $\left[\mathrm{PtCl}_{2}\left\{\left({ }^{t} \mathrm{BuNH}\right) \mathrm{P}\left(\mu-\mathrm{N}^{t} \mathrm{Bu}\right)_{2}\right.\right.$ $\mathrm{P}(\mathrm{O}) \mathrm{H}_{2}$ ] (7). All hydrogen atoms except $\mathrm{H}(\mathrm{P})$ and $\mathrm{H}(\mathrm{N})$ and all lattice solvent molecules are omitted for clarity. Thermal ellipsoids are drawn at the $50 \%$ probability level. Selected bond distances $[\AA]$ : Pt1-P1, 2.3062(8); Pt1-Cl1, 2.3116(7); Pt1-Cl1 ${ }^{\mathrm{i}}$, 2.3116(7); P2-O1, 1.467(2); P1-N2, 1.7006(19); P1-N3, 1.621(2); P2-N1, 1.6669(19); P2$\mathrm{N} 2,1.672(2) ; \mathrm{P} 2-\mathrm{H} 1,1.29(3)$. Selected bond angles [ $\left.{ }^{\circ}\right]: \mathrm{Cl1}-\mathrm{Pt} 1-\mathrm{P} 1$, 87.10(2); Cl1-Pt1-P1 ${ }^{\mathrm{i}}$, 92.90(2N1-P1-N2, 82.39(9).

and $2[1.468(2) \AA]$ are nearly identical. The exocyclic and endocyclic $\mathrm{P}-\mathrm{N}$ bond distances in $\mathbf{7}$ are shorter than that found in 2, but follow the same trend. ${ }^{32}$ In general, the exocyclic $\mathrm{P}-\mathrm{N}$ distances are shorter and comparable with typical P-N distances observed in both cyclic and acyclic diphosphazanes ${ }^{49}$ and $\mathrm{P}-\mathrm{N}$ bond distances associated with $\mathrm{P}^{\mathrm{V}}$ centers are shorter than that of $\mathrm{P}^{\mathrm{III}}$ centers in cyclodiphosphazanes.

\section{Conclusions}

The reactivity and transition metal chemistry of a mixed-valent cyclodiphosphazane derivative, cis$\left\{\left({ }^{t} \mathrm{BuNH}\right) \mathrm{P}\left(\mu-\mathrm{N}^{t} \mathrm{Bu}\right)_{2} \mathrm{P}(\mathrm{O}) \mathrm{H}\right\} \quad(2)$, has been studied. The compound $\mathbf{2}$ exists purely as the $c i$ is isomer in both solution and solid states but exhibits cis/trans isomerisation when coordinated to metal centres. The reaction of 2 with palladium(II) and platinum(II) precursors yielded a mixture of two isomers. In both the complexes isomers, the two cyclodiphosphazane rings adopt cis/cis and trans/trans conformations, but the mixed cis/trans conformation was not observed. The presence of two conformations of the cyclodiphosphazane rings was established by NMR spectroscopy and single crystal X-ray diffraction studies.

\section{Supplementary Information}

NMR spectra for compounds 3-7 are provided. The electronic supplementary information can be seen at www.ias.ac.in/chemsci. Crystallographic data for compounds $\mathbf{5}$ and $\mathbf{7}$ has been deposited at the Cambridge Crystallographic Data Centre with CCDC no. 1000229 (compound 5) and 1000230 (compound 7). These data can be obtained free of charge at www.ccdc.cam.ac. $\mathrm{ul} /$ conts/retrieving.html [or from the Cambridge Crystallographic Data Centre (CCDC), 12 Union Road, Cambridge CB2 1EZ, UK; fax: +44(0)1223-336033; E-mail: deposit@ccdc.cam.ac.uk].

\section{Acknowledgements}

We are grateful to the Science \& Engineering Research Board, New Delhi, India. for financial support of this work through grant No.SB/S1/IC-08/2014. GSA thanks CSIR, New Delhi, for Senior Research Fellowship (SRF). We also thank the Department of Chemistry Instrumentation Facilities, IIT Bombay, for spectral and analytical data. JTM thanks the Louisiana Board of Regents for the purchase of the CCD diffractometer and the Chemistry Department of Tulane University for support of the X-ray laboratory. 


\section{References}

1. Balakrishna M S, Eisler D J and Chivers T 2007 Chem. Soc. Rev. 36650

2. Stahl L 2000 Coord. Chem. Rev. 210203

3. Rastatter M, Muterle R B, Roesky P W and Thiele S K H 2009 Chem. Eur. J. 15474

4. Chandrasekaran P, Mague J T and Balakrishna M S 2006 Inorg. Chem. 456678

5. Schranz I, Lief G R, Carrow C J, Haagenson D C, Grocholl L, Stahl L, Staples R J, Boomishankar R and Steiner A 2005 Dalton Trans. 3307

6. Bond A D, Doyle E L, Garcia F, Kowenicki R A, McPartlin M, Riera L and Wright D S 2003 Chem. Commun. 2990

7. Lief G R, Carrow C J, Stahl L and Staples R J 2001 Chem. Commun. 1562

8. Grocholl L, Stahl L and Staples R J 1997 Chem. Commun. 1465

9. Balakrishna M S, Suresh D, Rai A, Mague J T and Panda D 2010 Inorg. Chem. 498790

10. Suresh D, Balakrishna M S, Rathinasamy K, Panda D and Mobin S M 2008 Dalton Trans. 2812

11. Axenov K V, Kotov V V, Klinga M, Leskelä M and Repo T 2004 Eur. J. Inorg. Chem. 695

12. Axenov K V, Klinga M, Leskela M, Kotov V and Repo T 2004 Eur. J. Inorg. Chem. 4702

13. Roth T, Wadepohl H, Wright D S and Gade L H 2013 Chem. Eur. J. 1913823

14. Ananthnag G S, Kuntavalli S, Mague J T and Balakrishna M S 2012 Inorg. Chem. 515919

15. Nordheider A, Chivers T, Thirumoorthi R, Vargas-Baca I and Woollins J D 2012 Chem. Commun. 486346

16. Calera S G and Wright D S 2010 Dalton Trans. 395055

17. Gonzalez-Calera S, Eisler D J, Morey J V, McPartlin M, Singh S and Wright D S 2008 Angew. Chem. Int. Ed. 47 1111

18. Dodds F, Garcia F, Kowenicki R A, McPartlin M, Steiner A and Wright D S 2005 Chem. Commun. 3733

19. Chakravarty M, Kommana P and Kumara Swamy K C 2005 Chem. Commun. 5396

20. Kommana P and Kumara Swamy K C 2000 Inorg. Chem. 394384

21. Chen H J, Haltiwanger R C, Hill T G, Thompson M L, Coons D E and Norman A D 1985 Inorg. Chem. 244725

22. Silaghi-Dumitrescu I, Lara-Ochoa F and Haiduc I 1998 Main Group Chem. 2309

23. Suresh D, Balakrishna M S and Mague J T 2008 Dalton Trans. 3272

24. Rastatter M and Roesky P W 2008 Eur. J. Inorg. Chem. 5287

25. Rastatter M, Roesky P W, Gudat D, Deacon G B and Junk P C 2007 Chem. Eur. J. 137410

26. Woods A D and McPartlin M 2004 Dalton Trans. 90

27. Reddy V S, Krishnamurthy S S and Nethaji M 1994 J. Chem. Soc., Dalton Trans. 2661

28. Kumaravel S S, Krishnamurthy S S, Cameron T S and Linden A 1990 J. Chem. Soc., Dalton Trans. 1119

29. Keat R, Keith A N, Macphee A, Muir K W and Thompson D G 1978 J. Chem. Soc., Chem. Commun. 372
30. Balakrishna M S, Venkateswaran R and Mague J T 2009 Inorg. Chem. 481398

31. Balakrishna M S, Suresh D and Mague J T 2011 Inorg. Chim. Acta 372259

32. Doyle E L, Garcia F, Humphrey S M, Kowenicki R A, Riera L, Woods A D and Wright D S 2004 Dalton Trans. 807

33. Vijjulatha M, Kumaraswamy S, Kumara Swamy K C and Engelhardt U 1999 Polyhedron 182557

34. Armarego W L and Perrin D D 1996 In Purification of Laboratory Chemicals 4th edition (UK: ButterworthHeinemann)

35. Bashall A, Doyle E L, Tubb C, Kidd S J, McPartlin M, Woods A D and Wright D S 2001 Chem. Commun. 2542

36. Tatsuno Y, Yoshida T and Otsuka S 1990 Inorg. Synth. 28342

37. Bennett M A, Huang T N, Matheson T W and Smith A K 1982 Inorg. Synth. 2174

38. Drew D and Doyle J R 1990 Inorg. Synth. 28346

39. APEX2, SADABS, SAINT and SHELXTL, Bruker-AXS, Madison, WI, 2009

40. Sheldrick G W 2008 SHELXL and SHELXS, Acta Cryst. A64 112

41. Kumara Swamy K C, Gangadhararao G, Srinivas V, Bhuvan Kumar N N, Balaraman E and Chakravarty M 2011 Inorg. Chim. Acta 372374

42. Kumara Swamy K C, Gangadhararao G, Rama Suresh R, Bhuvan Kumar N N and Chakravarty M 2010 J. Organom. Chem. 6951042

43. Crystal data for 5: $\mathrm{C}_{22} \mathrm{H}_{43} \mathrm{Cl}_{2} \mathrm{~N}_{3} \mathrm{OP}_{2} \mathrm{Ru}$, fw $=599.50$, Orthorhombic, Pna21 (No. 33), a = 13.383(6) $\AA$, b = 16.425(7) $\mathrm{\AA} \mathrm{c}=12.607(6) \AA \mathrm{V}=2771(2) \AA^{3}, \mathrm{Z}=$ $4, \rho_{\text {calc }}=1.437 \mathrm{gcm}^{-3}, \mu\left(\mathrm{MoK}_{\alpha}\right)=0.893 \mathrm{~mm}^{-1}$, $\mathrm{F}(000)=1248, \mathrm{~S}=1.03, \mathrm{~T}=100 \mathrm{~K}$. A total of 45,206 reflections were processed; of which, 7,190 were unique $\left(\mathrm{R}_{\text {int }}=0.063\right)$. The final $\mathrm{wR}$ value was 0.0592 (all data) and $\mathrm{R}=0.024[\mathrm{I}>2 \mathrm{r}(\mathrm{I})]$. Crystal data for 7 : $\mathrm{C}_{24} \mathrm{H}_{58} \mathrm{Cl}_{2} \mathrm{~N}_{6} \mathrm{O}_{2} \mathrm{P}_{4} \mathrm{Pt}$, fw $=852.62$, Monoclinic, $P 21 / n$ (No. 14), $\mathrm{a}=9.2580(15) \AA, \mathrm{b}=8.7540(14) \AA \mathrm{c}=$ 22.885(4) $\AA, \beta=98.053(2)\left[{ }^{\circ}\right], \mathrm{V}=1836.4(5) \AA^{3}, \mathrm{Z}$ $=2, \rho$ calc $=1.542 \mathrm{gcm}^{-3}, \mu\left(\mathrm{MoK}_{\alpha}\right)=4.170 \mathrm{~mm}^{-1}$, $\mathrm{F}(000)=864, \mathrm{~S}=1.02, \mathrm{~T}=100 \mathrm{~K}$. A total of 12941 reflections were processed; of which, 3,178 were unique $\left(R_{\text {int }}=0.025\right)$. The final wR value was 0.0431 (all data), $\mathrm{R}=0.0175$ [I $>2 \mathrm{r}(\mathrm{I})]$

44. Chandrasekaran P, Mague J T and Balakrishna M S 2008 Polyhedron 2780

45. Gudat D, Jain V K, Klein A, Schurr T and Záliš S 2005 Eur. J. Inorg. Chem. 20054056

46. Chauhan R S, Kedarnath G, Wadawale A, Maity D K, Golen J A, Rheingold A L and Jain V K 2013 J. Organomet. Chem. 73740

47. Chauhan R S, Sharma R K, Kedarnath G, Cordes D B, Slawin A M Z and Jain V K 2012 J. Organomet. Chem. 717180

48. Balakrishna M S, Venkateswaran R and Mague J T 2010 Dalton Trans. 3911149

49. Balakrishna M S, Reddy V S, Krishnamurthy S S, Nixon J F and Laurent J C T R B S 1994 Coord. Chem. Rev. 1291 